\title{
TÖLGYTERMÉS ELŐKEZELÉSEK HATÁSÁNAK VIZSGÁLATA A MAKKLISZT SZENZOROS ÉRTÉKELÉSÉVEL
}

\author{
Migaskó Helga Szilvia - Ecseri Károly
}

\begin{abstract}
Absztrakt: Vizsgálatunkban az egykoron ínségételként is használt kocsányos tölgy (Quercus robur) makkjának elökezelését végeztük el különböző eljárásokat alkalmazva (hamuban pirítás, fagyasztás, elősütés, forrázás), a magban található tannintartalom csökkentése céljából. A megőrölt magtételekből sütött lepényeket ezt követően organoleptikus bírálatban értékeltük 32 bíráló segítségével. Az alkalmazott kezelések közül a legrosszabb értékeket a hamuban kezelt termések mutatták. Ezt az eredményt a vizsgált öt paraméter közül háromban (szín, keménység, nedvesség) a statisztikai adatok is alátámasztották. A másik két szempont esetében (illat, utóíz) szignifikáns differenciát nem tapasztalunk. Ebben a kísérletben nem volt különbség a bírálók nemére, életkorára és iskolai végzettségére vonatkozóan sem az egyes kezelések között.
\end{abstract}

Abstract: Seeds of oak used as a famine food formerly. Pre-treatment of the oak acorn (Quercus robur) was performed using different methods (roasting in ash, freezing, baking, boiling) to reduce the tannin content in the seed. After baking ground acorns were evaluated by sensory testing with 32 testers. The worst values were in case of ash-treated seeds. This result was also supported by statistical data in case of three parameters (colour, hardness, moisture). There is no significant difference in the other two parameters (fragrance, aftertaste). There was no difference among the treatments between the sexes, age and educational qualification of the judges.

Kulcsszavak: kocsányos tölgy, tannin tartalom, érzékszervi bírálat, funkcionális élelmiszer

Keywords: pedunculate oak, tannin content, sensory testing, functional food

\section{Bevezetés}

A történeti időkben gyakori vadgyümölcs fogyasztás Magyarországon a 20. század végére gyakorlatilag eltünt. A csökkenés elsősorban az alföldi területeken érezhető, ugyanakkor egyes erdélyi falvakban mind a mai napig használnak akár 20-30 növényfajt is. Napjainkban az egészségtudatos táplálkozás, illetve a gazdasági válság hatására újra feléledt a vad fajok gyüjtésének és fogyasztásának kultusza (DÉNES és mtsai., 2013).

Az egyik ilyen „vadgyümölcsöt” termö nemzetség a tölgyek (Quercus) csoportja. Ezen növények termését fontos ínségeledelként tartották számon több európai, illetve ázsiai és amerikai területen. Használták kávé és lisztpótlásra, illetve gyermek csemegeként, tinta készítésre, valamint távol-keleten keményítő és alkohol előállításra is (ČEMAN, 2007; KALLE and SŐUKAND, 2012; ŁUCZAJ, 2012; MCCORRISTON, 1994; RÁCZ, 2013).

Egy jelentős probléma ugyanakkor ezen fák termésének magas tannin-tartalma. Ezeknek a polifenol vegyületeknek több pozitív hatását is igazolták, kis mennyiségben való fogyasztásuk kifejezetten ajánlott (CHUNG et al., 1998). Elterjedését, illetve térhódítását viszont nagymértékben hátráltatja az a tény, hogy a tannin tartalmú élelmiszerek keserü utóízzel rendelkeznek. Ennek csökkentésére több módszer is megtalálható az irodalmakban, például hőkezelés, áztatás, préselés stb. (MASON, 1992; MASON and NESBITT, 2009). 
Egy csehországi kísérletben megállapították, hogy búzaliszthez keverve kellemesebb ízü, mint önmagában felhasználva. Az alkalmazott előkezelések (főzés puhulásig, pirítás illetve fözés-pirítás) között nem volt különbség az érzékszervi bírálat során. A vizsgálat alapján nem játszik jelentős szerepet az előkészítési mód a tölgymakkból készített élelmiszerek ízében, inkább a jelentős energia és időbefektetés hátráltatja az ilyen jellegü élelmiszerek elterjedését. A kutatók kiemelik, hogy egyes fák között kisebb ízbeli különbségek lehetnek az eltérö ökológiai tényezők miatt. Meglepő eredmény, hogy a kóstolás során a cseh emberek hasonlóan pontozták a tölgymakk lisztböl készült kekszeket, mint a közönséges rizslisztből készült kenyeret (ŠÁLKOVÁ et al., 2011).

Ezen kísérlet eredményeit figyelembe véve terveztük meg és hajtottuk végre saját vizsgálatunkat a tölgymakkliszt fogyaszthatóságának megállapítására.

\section{Anyag és módszer}

A kísérlet alapanyagául szolgáló terméseket az Alföld északi és középső részén (Kecskemét, Nagykőrös, Cegléd) található Quercus robur fák alól gyüjtöttük 2018. októberében. A gyüjtés során igyekeztünk a szakirodalomban ismertetett teljes érettségnek megfelelö morfológiai paramétereket szem elött tartani, illetve az egészséges és nem léha makkokat begyüjteni. A terméseket szobahőmérsékleten szárítottuk, majd különböző előkezeléseket végeztünk az egyes magtételeken. A kezelések az alábbiak voltak:

a) Kontroll (KONT), meghámozott, majd szobahőmérsékleten szárított.

b) Hamus (HAMU), akácfahamuba (parázsba) helyezett, majd kihülést követően meghámozott.

c) Fagyasztott (FAGY), hámozást követően 2018. október 31-től 2018. december 11-ig mínusz $24^{\circ} \mathrm{C}$-on tárolt.

d) Sütőben pirított (SUTO), hámozást követően kb. $200^{\circ} \mathrm{C}$-on, előmelegített sütőben hőkezelt.

e) Forrázott (FORR), hámozást követően forrásban lévő vízzel leöntött, majd letakart és gőz fölött párolt.

Az előkezeléseket követően a tételeket a Kertészeti és Vidékfejlesztési Kar Laboratóriumának terménydarálóján liszté őrölték. Ezt követően az így kapott alapanyagból elkészítettük a kóstoló falatokat a következő recept alapján:

$5 \mathrm{dkg}$ makkliszt $+5 \mathrm{dkg}$ búzaliszt $+4 \mathrm{~g}$ só $+80 \mathrm{ml}$ víz.

Az összegyúrt tésztából golyókat formáztunk (kb. 20 db-ot kezelésenként), melyeket ellapítva helyeztük a nyers masszát a sütőpapírral kibélelt tepsibe. Ezt követően elömelegített sütőben 20-25 percig sütöttük, takarék fokozaton.

Az elkészült pékárut kóstolásra kínáltuk, melyhez bírálati lapot készítettünk ( 1 . táblázat). Ebben ötféle szempontot kellett a vállalkozóknak pontoznia. Az 5-ös szám minden esetben a semlegest/közömböst/közepest jelentette, a két szélsöértéket pedig zárójelben tüntettük fel (LAWLESS and HEYMANN, 2010). 


\section{1. táblázat: Tölgymakk lisztből készített élelmiszerek pontozási táblázata}

\begin{tabular}{|c|c|c|c|c|c|}
\hline SZEMPONTOK & A & B & C & D & E \\
\hline SZÍN (1 - sötét, 9 - világos) & & & & & \\
\hline ILLAT (1 - kellemetlen, 9 - kellemes) & & & & & \\
\hline KEMÉNYSÉG (1 - kemény, 9 - puha, omlós) & & & & & \\
\hline NEDVESSÉG (1 - száraz, 9 - olajos, nedves) & & & & & \\
\hline UTÓÍZ (1 - keserü, 9 - nem keserü) & & & & & \\
\hline
\end{tabular}

Forrás: a szerzők saját szerkesztése.

\section{Eredmények és értékelésük}

\subsection{Kezelések összehasonlítása az összes bírálók esetében}

Az ötféle vizsgált paraméter (szín, illat, keménység, nedvesség, utóíz) korreláció vizsgálata során a Pearson féle elemzés szignifikáns kapcsolatok tárt fel több esetben is. Egyedül a szín és nedvesség párba állítása során nem volt kimutatható korreláció (SL>0,05), ezért ezt a két adatsort a többitől külön vizsgáltuk, míg a másik három tulajdonság esetében (illat, keménység, utóíz) a háromtényezős varianciaanalízis módszerét alkalmaztuk.

A háromtényezős MANOVA szignifikáns hatást mutatott (Wilks féle lambda értéke $\mathrm{F}=6,54, \mathrm{SL}<0,001)$. A csoportokon belüli szórások mindhárom paraméter esetében homogénnek tekinthetők (Levene teszt $\mathrm{SL}>\alpha$ ), de a kezelésnek csak a keménységre volt kimutatható hatása $(\mathrm{F}=20,88 \mathrm{SL}<0,001)$. A másik két adatsor esetében nem volt megfigyelhető szignifikáns különbség (SL>0,1). A keménység értékek rezidumainak normalitását elfogadtuk (Kolmogorov-Smirnov teszt: SL>0,05), így a páronkénti összehasonlítás vizsgálata is lehetségessé vált. A Tukey teszt három csoportot különített el (2. táblázat).

2. táblázat: A tölgymakk liszt elökezelésének hatása a termék keménységére

\begin{tabular}{|c|c|c|c|c|}
\hline \multirow{2}{*}{ KEZELÉS } & \multirow{2}{*}{$\mathrm{N}$} & \multicolumn{3}{|c|}{ Keménység } \\
\cline { 3 - 5 } & & 1 & 2 & 3 \\
\hline HAMU & 32 & 2,87 & & \\
SÜTŐ & 32 & & 5,28 & \\
KONT & 32 & & 5,72 & 5,72 \\
FORR & 32 & & 6,16 & 6,16 \\
FAGY & 32 & & & 6,59 \\
\hline
\end{tabular}

Forrás: A szerzők saját szerkesztése. 
A hamuban pirított magtétel keménysége $(2,87)$ szignifikánsan alacsonyabb volt az összes többi kezelésétől. Statisztikailag igazolható különbség még a sütőben hökezelt és a fagyasztott makkok között volt, míg a kontroll és a forrázott termésekből készített élelmiszerek keménysége mindkét kategóriába beletartozott.

A színadatok vizsgálata során a kezeléseknek szintén szignifikáns hatását lehetett megfigyelni $(\mathrm{F}=31,5 \mathrm{SL}<0,001)$. A hibatagok normalitását Tabachnick \& Fidell, 2013 alapján elfogadtuk (+1,5 és -1,5 közötti intervallumban volt). A Levene teszt eredménye alapján $(\mathrm{SL}>\alpha)$ a páronkénti összehasonlítás vizsgálatnál a Tukey tesztet alkalmaztuk. Az analízis elvégzésével négy csoport jött létre (3. táblázat). Szignifikánsan legkisebb (legsötétebb színü) a hamuban pirított magtétel. Világosabbnak ítélték a bírálók a sütőben hőkezelt makkokat, míg közel semlegesnek a fagyasztott terméseket. A forrázás, mint elökezelés nem különbözött az előző két adatsortól. Legsötétebbnek egyértelmüen a kontroll minta bizonyult ebben a kísérletben (3. táblázat).

\section{3. táblázat: A tölgymakk liszt előkezelésének hatása a termék színére}

\begin{tabular}{|c|c|c|c|c|c|}
\hline \multirow{2}{*}{ KEZELÉS } & \multirow{2}{*}{$\mathrm{N}$} & \multicolumn{4}{|c|}{ Szín } \\
\cline { 3 - 6 } & & 1 & 2 & 3 & 4 \\
\hline HAMU & 32 & 2,19 & & & \\
SÜTŐ & 32 & & 4,13 & & \\
FORR & 32 & & 5,25 & 5,25 & \\
FAGY & 32 & & & 5,38 & \\
KONT & 32 & & & & 6,69 \\
\hline
\end{tabular}

Forrás: A szerzők saját szerkesztése.

A nedvesség elemzéshez szükséges feltételek teljesültek (a rezidumok normalitását a csúcsosság ferdeség alapján elfogadtuk), és a varianciaanalízis is kimutatta a kezelés hatását $(\mathrm{F}=4,66 \mathrm{SL}<0,05)$. A Levene teszt eredmények alapján (SL>0,05), a páronkénti összehasonlításhoz a Tukey tesztet alkalmaztuk. Az eredmények fényében megállapítható, hogy a hamuban előkezelt magtétel a bírálók véleménye szerint szárazabbnak bizonyult, mint a kontroll, a fogyasztott és a forrázott makkok. A sütőben hőkezelt termések tekintetében nem volt kimutatható különbség (4. táblázat). 
4. táblázat: A tölgymakk liszt előkezelésének hatása a termék nedvességtartalmára

\begin{tabular}{|c|c|c|c|}
\hline \multirow{2}{*}{ KEZELÉS } & \multirow{2}{*}{ N } & \multicolumn{2}{|c|}{ Nedvesség } \\
\cline { 3 - 4 } & & 1 & 2 \\
\hline HAMU & 32 & 3,69 & \\
SÜTŐ & 32 & 4,97 & 4,97 \\
KONT & 32 & & 5,44 \\
FAGY & 32 & & 5,78 \\
FORR & 32 & & 5,78 \\
\hline
\end{tabular}

Forrás: A szerzők saját szerkesztése.

Bár az utóízek tekintetében nem volt szignifikáns eltérés, a kapott adatsort megvizsgálva mégis megállapítható, hogy több bíráló is a hamuban előkezelt mintát ítélte leggyengébbnek (1. ábra). Ebben az esetben volt a legtöbb igen rossz (1) pontszám $(5 \mathrm{db})$, illetve szintén ezt a terméket értékelte a legkevesebb bíráló (4 db) egyáltalán nem keserünek (9). A semlegesnél rosszabb, keserübb (<5) utóízt a legtöbb válaszadó elsősorban a sütőben illetve a hamuban hökezelt makkok esetében érezte. Kellemes, kevésbé vagy nem keserü ízünek (>5) elsősorban a kontroll és a fagyasztott minták bizonyultak 22-22 bíráló véleménye szerint (1. ábra). Leginkább semlegesnek a forrázott termésből készült tétel bizonyult, melyet az összes bíráló 21,87\%-a értékelt 5-ösre.

\section{1. ábra: A tölgymakk liszt előkezelések hatása a termék utóízére}

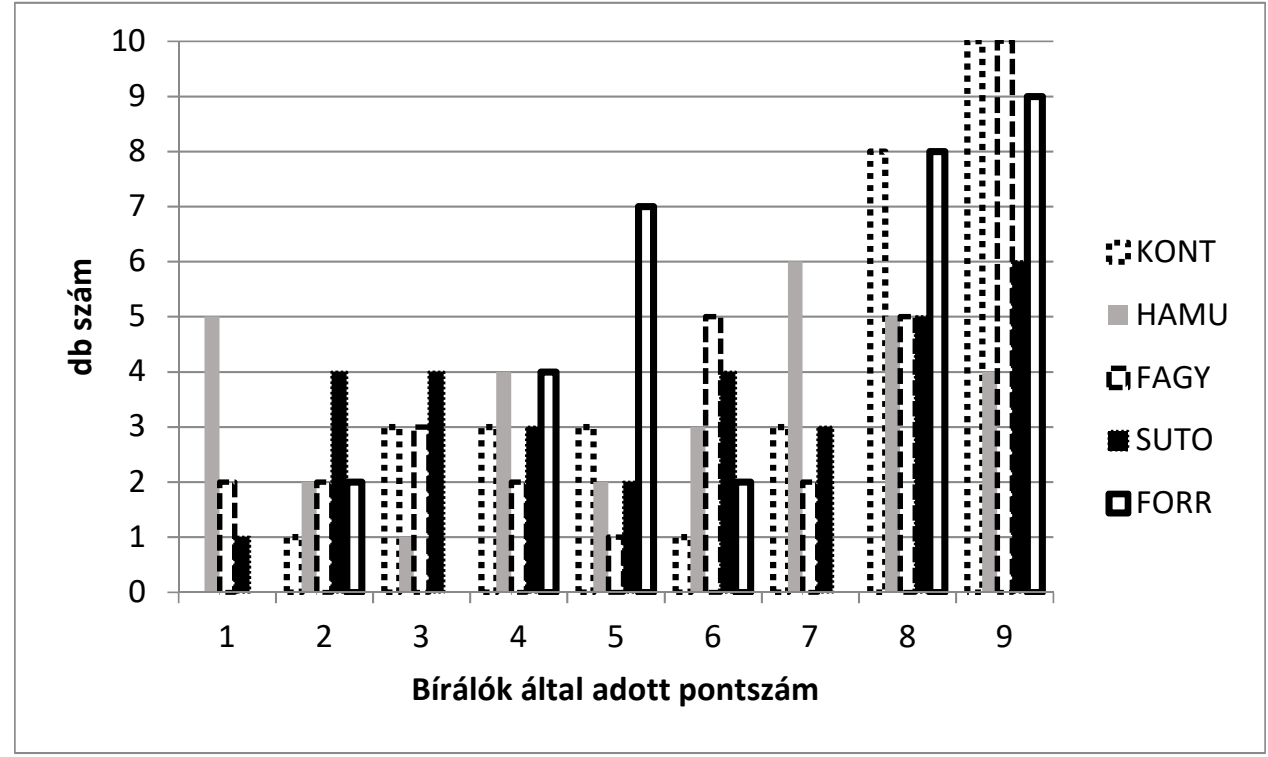

Forrás: A szerzők saját szerkesztése. 


\subsection{Kezelések összehasonlítása a férfiak-nők esetében}

A bírálók megoszlása nemek alapján: 17 nő, 15 férfi. A regresszió vizsgálat elemzése során szignifikáns különbséget nem lehetett kimutatni a nemek között egyik paraméter tekintetében sem $(\mathrm{R}=0,232$, ANOVA F=1,753; $\mathrm{SL}>0,1)$.

\subsection{Kezelések összehasonlítása a bírálók életkora alapján}

A válaszadók közül 15 fö 50 év alatti, míg 17 fö 50 év feletti életkorú. A regressziós modell megvizsgálva hasonló eredményt tapasztaltunk, mint a nemek esetében. Statisztikailag kimutatható különbség itt sem volt egyik mért érték vonatkozásában sem az életkort figyelembe véve ( $\mathrm{R}=0,116$, ANOVA F=0,418; $\mathrm{SL}>0,8)$.

\subsection{Kezelések összehasonlítása az iskolai végzettség alapján}

Az értékelő lapot kitöltők között 15 fő rendelkezett általános vagy középfokú; míg 17 fö felsőfokú iskolai végzettséggel. A lineáris regresszió itt sem volt megfigyelhető a két csoport között ( $\mathrm{R}=0,207$, ANOVA F=1,375; SL>0,2).

\section{Következtetések}

Az eredményekből megállapítható, hogy statisztikailag igazolható különbség csak a keménység, a szín és a nedvesség tartalom esetében volt megfigyelhető a kezelések között. Ezekben a paraméterekben a hamuban hökezelt makktétel szignifikánsan gyengének bizonyult. Ugyanez az eredmény volt megfigyelhető az utóíz tekintetében is. Ezekből az adatokból megállapítható, hogy ez az előkezelés - a szakirodalmi adatokkal ellentétben - a legkedvezőtlenebb a Quercus robur esetében. Megjegyzendő, hogy a kellemetlen szín és ízhatás sokkal nagyobb mértékü lehet, amennyiben a kísérletünkben alkalmazott $50 \%$-os búzaliszt arányt csökkentjük, vagy teljesen elhagyjuk. Utóíz tekintetében ugyanakkor nem volt szignifikáns különbség a vizsgált 5 minta között, amely az elvégzett előkezelések hasznosságát is megkérdőjelezi. Ennél a fajnál a tannintartalom csökkentésére (és ezáltal a keserü utóíz elnyomására) alternatív megoldást kell találni, hogy a makklisztből készített élelmiszerek élvezeti értéke javuljon és ezzel felhasználási lehetőségei növekedjenek.

\section{Köszönetnyilvánítás}

Köszönettel tartozunk a kutatás támogatásáért, amely az EFOP-3.6.2-16-201700012 „Funkcionális, egészséges és biztonságos élelmiszer termékpálya modell kidolgozása a szántóföldtől az asztalig elv alapján, tematikus kutatási hálózatban” pályázat keretében valósult meg.

\section{Irodalomjegyzék}

Čeman, R. (2007): Élö természet - Növényvilág. Földrajzi enciklopédia, rekordok sorozat. SlovartPrint, Pozsony. 176-181. o.

Chung, K.-T., Wong, T. Y., Wei, C-I., Huang, Y.-W. and Lin, Y. (1998): Tannins and Human Health: A Review. Critical Reviews in Food Science and Nutrition. 38(6): 421-464. 
Dénes A. - Papp N. - Babai D. - Czúcz B. - Molnár ZS. (2013): Ehető, vadon termő növények és felhasználásuk a Kárpát-medencében élő magyarok körében néprajzi és etnobotanikai kutatások alapján. Dunántúli Dolgozatok (A) Természettudományi Sorozat. 13:35-76.

Kalle, R., Sőukand, R. (2012): Historical ethnobotanical review of wild edible plants of Estonia (1770s-1960s). Acta Societatis Botanicorum Poloniae. 81(4):271-281.

Lawless, H. T. and Heymann, H. (2010): Sensory Evaluation of Food. Principles and Practices. Second Edition. Springer. New York.

Łuczaj, Ł. (2012): Ethnobotanical review of wild edible plants of Slovakia. Acta Societatis Botanicorum Poloniae. 81(4): 245-255.

Mason, S. and Nesbitt, M. (2009): Acorns as food in southeast Turkey: Implications for prehistoric subsistence in Southwest Asia. IN: A. S. Fairbairn and E. Weiss (2009): From Foragers to Farmers: Papers in Honour of Gordon C. Hillman. OXBOW BOOKS, Oxford and Oakville. pp. 71-85.

Mason, S. L. R. (1992): Acorns in human subsistence. Institute of archeology, Universtiy College. London. pp. 69-70, 76.

Mccorriston, J. (1994): Acorn eating and agricultural origins: California ethnographies as analogies for the ancient Near East. Antiquity 68: 97-107.

Rácz G. - Rácz-Kotilla E. - Szabó L. Gy. (2012): Gyógynövények ismerete. A fitoterápia és az alternatív medicina alapjai. Galenus Kiadó, Budapest. 347-348. o.

Šálková, T., Divišová, M., Kadochová, Š., Beneš, J., Delawská, K., Kadlčková, E., Němečková, L., Pokorná, K., Voska, V., Žemličková, A. (2011): Acorns as a Food Resource. An Experiment with Acorn Preparation and Taste. Interdisciplinaria Archaeologica. Volume II. Issue 2: 133141.

Tabachnick, B. G., Fidell, L. S. (2013): Using Multivariate Statistics. 6th edition. Boston: Pearson. 